\title{
Diversity of VAM in soils used to cultivate sugarcane (Saccharum spp.) in Tabasco, Mexico
}

\author{
Payró de la Cruz, Emeterio $^{1}$; Salgado-García, Sergio ${ }^{2}$; De los Santos-López, Guadalupe ${ }^{1}$; \\ Castelán-Estrada, Mepivoseth ${ }^{2 *}$; Górdova-Sánchez Samuel ${ }^{3}$; Gómez-Leyva, Juan F. ${ }^{4}$; \\ Hernández-Cuevas, Laura ${ }^{5}$ \\ 1 Instituto Tecnológico de la Zona Olmeca. Ignacio Zaragoza s/n. Villa Ocuitzapotlán, Centro, Tabasco. CP. \\ 86270. \\ 2 Colegio de Postgraduados-Campus Tabasco, Grupo MASCAÑA. Km. 3.5 Periférico Carlos A. Molina S/N. \\ H. Cárdenas, Tabasco. CP 86500. México. \\ 3 Universidad Popular de la Chontalpa. División Académica de Ciencias Básicas e Ingenierías. CA-QVyDS. \\ Carretera Cárdenas-Huimanguillo, Km. 2.0 Cárdenas, Tabasco, México. CP. 86500. \\ 4 Tecnológico Nacional de México/IT Tlajomulco. km 10 Carretera Tlajomulco-San Miguel de Cuyutlán. \\ 45640, Tlajomulco de Zuñiga, Jalisco. \\ 5 Centro de Investigación en Genética y Ambiente. Universidad Autónoma de Tlaxcala. Autopista Texmelucan- \\ Tlaxcala Km 10.5. Ixtacuixtla CP. 90120, Tlaxcala, México. \\ * Corresponding author: mcastelan@colpos.mx
}

Gitation: Payró de la Cruz, E., Salgado-García, S., De los SantosLópez, G., Castelán-Estrada, M., Córdova-Sánchez, S., Gómez-Leyva, J. F., Hernández-Cuevas, L. (2021) Diversity of vam in soils used to cultivate sugarcane (Saccharum spp.) in Tabasco, Mexico. Agro Productividad. https://doi.org/10.32854/agrop. v14il1.2078

Editor in Chief: Dr. Jorge Cadena Iñiguez

Received: June 2, 2021.

Accepted: October 14, 2021.

Published on-line: December 1, 2021.

This work is licensed under a Creative Commons Attribution-NonCommercial 4.0 International license.

\begin{abstract}
Objective: A study was carried out in the Ingenio Santa Rosalía sugar mill supply area with the aim of identifying the soil subunits cultivated with sugar cane and to quantify the degree of mycorrhization of Saccharum officinarum.

Design/Methodology/Approach: Rhizosphere samples were collected at a depth of 0-30 $\mathrm{cm}$ and root segments with diameters of $\leq 1 \mathrm{~mm}$ and 1-2.0 $\mathrm{mm}$ were studied. The intersect method and the fungal structures method were comparatively analyzed to determine the mycotrophic state of the roots. The study also quantified the number of spores in the soils and classified the morpho-species of vesicular-arbuscular mycorrhiza (VAM). Results: The results show that seven soil subunits exist in the area, but the intersect method did not detect differences in colonization by root diameter or by root colonization $(\overline{\mathrm{X}}=68.5 \%)$. For its part, the fungal structures method showed differences in colonization between soil subunits $(\overline{\mathrm{X}}=69.5 \%)$, being higher in thin roots, and statistical differences wer found for vesicles and spores. At the sites, an average of 696 spores was quantified per $100 \mathrm{~g}$ of soil, which indicates a high presence of vesicular-arbuscular mycorrhizal fungi in the study area. Finally, six species of mycorrhizae were identified, of which four are present in various soil subunits: Glomus aff. deserticola, Glomus etunicatum, Glomus viscosum, and Paraglomus occultum.
\end{abstract}

Study Limitations/Implications: This was an exploratory study that indicates the potential of VAM on sugarcane.

Findings/Conclusions: The presence of hyphae, vesicles, arbuscules, and spores indicates that there is an active mycotrophic process between VAM and sugarcane cultivation in the soils of the study area.

Index words: arbuscular mycorrhizae, endophytes, sugar mill, vesicles.

\section{INTRODUGTION}

The Ingenio Santa Rosalía is the second most economically important sugarcane mill in Tabasco, Mexico, both for the cultivated area and for its production of grinding stalks. During the 2017/2018 season, 823,264 tons of sugarcane were harvested in an area of 12,268 ha. The average field yield for this cycle was $67 \mathrm{tha}^{-1}$ with a factory 
sugar yield of 7,298 $\mathrm{kg} \mathrm{ha}^{-1}$ (UNC, 2018). The yields of grinding stalks and sugar are low and are due in part to the poor management of fertilization, since the specific fertilizer recommendations for each type of soil in the supply area have not been followed (Salgado et al., 2005). In recent decades, the term biofertilizers has been introduced in the scientific literature, and refers to consortia of bacteria and mycorrhizal fungi that can provide $\mathrm{N}$, $\mathrm{P}$, and water for crop nutrition, as well as growth-promoting substances (gibberellins and indoleacetic acid), sulfur oxidation, increased root permeability, and siderophore production (Requena et al., 2007; Azevedo, 2008). The subject has awakened interest due to the possibility of lowering fertilization costs, as well as reducing the impacts of excessive fertilizer use, especially nitrogen.

The active dynamics of nutrient exchange, reproduction, and survival in adverse conditions have endowed mycorrhizal fungi with highly specialized structures such as hyphae, vesicles, arbuscules, and spores, all of which could be indicators of the mycotrophic state of the plants with which they are associated (Barea et al., 2005). For its part, the root system of sugarcane is made up of segments with different thicknesses and degrees of lignification that could cause mycorrhizal structures to be differentially present (Sánchez-Reyna et al., 2020). The intersect method is the most commonly used to determine the degree of mycorrhization (Giovannetti and Mose, 1980), while the fungal structures method (McGonigle et al., 1990) that takes into account several structures of the fungus present in the root (hyphae, vesicles, arbuscules, and spores) is less common. Therefore, the objective of this study was to determine the mycotrophic status of VAM in soils cultivated with sugarcane within the supply area of the Ingenio Santa Rosalía sugar mill in Tabasco, Mexico.

\section{MATERIALS AND METHODS}

Description of the study area. The Santa Rosalía (ISR) sugar mill is located in the Municipality of Cárdenas, Tabasco, at an altitude of $12 \mathrm{~m}$ above sea level. The region is part of the Gulf Coastal Plain, with average annual temperature of $26^{\circ} \mathrm{C}$, average rainfall of $1870 \mathrm{~mm}$ per year, and average annual relative humidity of $83 \%$ (Salgado et al., 2005). The ISR supply area covers a surface of more than 12,000 ha of sugarcane plantations (UNG, 2018).

Collection of soil and roots. Seven soil subunits growing sugarcane were identified, corresponding to the Fluvisol, Vertisol, and Gleysol types, with neutral or moderately acidic pH (Salgado et al., 2005). Four rhizosphere samples were collected from each soil subunit, which were considered repetitions. Each sample was taken at $20 \mathrm{~cm}$ from the stump and at a depth of 0-30 cm. Between each sampling, tools were fired to avoid cross contamination (Salgado et al., 2013). The samples were stored in labeled bags and transported $\left( \pm 4^{\circ} \mathrm{C}\right.$ ) to the Biotechnology laboratory of the Instituto Tecnológico de la Zona Olmeca.

Clarifying and staining of roots. Thirty (30) root segments were taken (thin and thick), which were washed with running water to remove clinging soil; excess water was removed by placing them on absorbent paper. Afterwards, $2 \mathrm{~cm}$-long portions of the root were cut and then immersed in the FAA solution for clarifying and staining. They were then rinsed to eliminate excess FAA solution and $\mathrm{KOH}$ at $10 \%$ was added, covering the 
roots completely; they were immersed in this solution for 24 hours or more, until the roots were clarified. Subsequently, excess $\mathrm{KOH}$ was decanted and the roots were washed with running water and soaked for 5 to $10 \mathrm{~min}$ in $\mathrm{HCl}$ at $10 \%$. Subsequently, the $\mathrm{HCl}$ was decanted and the roots were washed with running water. Finally, trypan blue $0.05 \%$ was added for $24 \mathrm{~h}$; after this time, the dye was decanted and the roots were placed in Petri dishes with lactoglycerol to remove excess dye (Phillips and Hayman, 1970).

\section{Study variables}

Root thickness. The root segments of each thickness, including thin roots (diameter $\leq 1 \mathrm{~mm}$ ) and thick roots (diameter $1 \mathrm{~mm}$ to $\leq 2.0 \mathrm{~mm}$ ), were observed independently to determine the degree of mycorrhization with each of the methods used.

Intersect method (Giovannetti and Mosse, 1980). The root segments were evenly distributed in $8.5 \mathrm{~cm}$ diameter, glass square Petri dishes with grids $(0.5 \times 0.5 \mathrm{in})$. Observations were made with a Leica brand $35 \mathrm{X}$ stereo microscope using the following equation:

$$
C=(T R C H+T R C V / T R H+T R V) \times 100
$$

where: $C=$ Colonization (\%); TRCH=Total colonized horizontal roots; TRCV=Total colonized vertical roots; $T R H=$ Total horizontal roots; $T R V=$ Total vertical roots.

Fungal Structures method (McGonigle et al., 1990). The roots were placed in permanent preparations on microscope slides, with 12 horizontal roots and 100 observations under the microscope for each preparation (100\%). Afterward, 2 or 3 drops of PVLG were added, they were left to dry for $5 \mathrm{~min}$, and then covered with a coverslip; these preparations were allowed to dry for a week. Subsequently, the preparations were read by fields of view with the 10x and 40x objectives in a Leica brand microscope, until 100 observations were made. Colonization by hyphae, vesicles, arbuscules, or spores was calculated using the following equation:

$$
C=(T C C / T C O) \times 100
$$

where: $C=$ Colonization (\%); $T C C=$ Total colonized fields; $T C O=$ Total observed fields.

Spore extraction. The successive wet sieving and decantation technique was used in combination with the sugar flotation technique (Salgado et al., 2014). Observations and counts were done under a Leica brand $35 \mathrm{X}$ stereo microscope.

Morphological classification of species. Once the spores were extracted from the soil samples, they were grouped and quantified according to their morphological characteristics by size, color, support hypha, and spore shape. The taxonomic classification of the morpho-species was made based on the INVAM (2018) keys.

Statistical analysis. Analyses of variance (ANOVA) were performed in a $7 \times 2$ factorial design (7 soil subunits and 2 root thicknesses) with four repetitions using the STATGRAPHICS plus 5.1 software; Tukey's means comparison test $(\alpha=0.05)$ was also used. 


\section{RESULTS AND DISGUSSION}

Fungal Structures method. Figure 1 shows the fungal structures observed in the cane roots. The hyphae and spores branch out inside the cortical cells and between the cells of the epidermis, confirming that they do not invade the root pith and that the mycorrhization process occurs naturally in this crop, as reported by Jiménez et al. (2010) for the soils cultivated with sugarcane from the Ingenio Presidente Benito Juárez (IPBJ) sugar mill in Tabasco.

The ANOVA performed by fungal structures showed significant differences in the main effect of root thickness on hyphae, vesicles, and arbuscules (Figure 2), with the highest percentages observed in thin roots. This indicates that the symbiotic association is very dynamic and that it is taking place differentially in the plant roots, which could be influenced by their functions. That is, in addition to different functions, the diameter of the roots could implicate different ages and lignification, among other factors that could affect colonization. The mean colonization with this method was $69.5 \%$, similar to the intersect method, which allows to infer that there is an interaction between VAM and sugarcane cultivation (Soria et al., 2001), although it is unclear if this relationship is positive or negative since VAMs can demand up to $15 \%$ of the carbohydrates produced by the host. The structures with the greatest presence were hyphae and vesicles, whose functions are transport and storage, respectively, without dismissing the important role they play in the spread of mycorrhizal fungi. The presence of arbuscules was low and since they are the structures through which mycorrhizal fungi deposit nutrients in the cell cytoplasm (Smith and Read, 2008), this could indicate that the nutritional state is not being benefitted. The presence of spores within the root system could be indicative of the mycorrhiza species present, since not all have the ability to form these structures within the roots (Souza, 2006).

Significant differences were found in the main effect of the soil subunits on all fungal structures (Table 1). A greater hyphae colonization was found in the moderately acidic

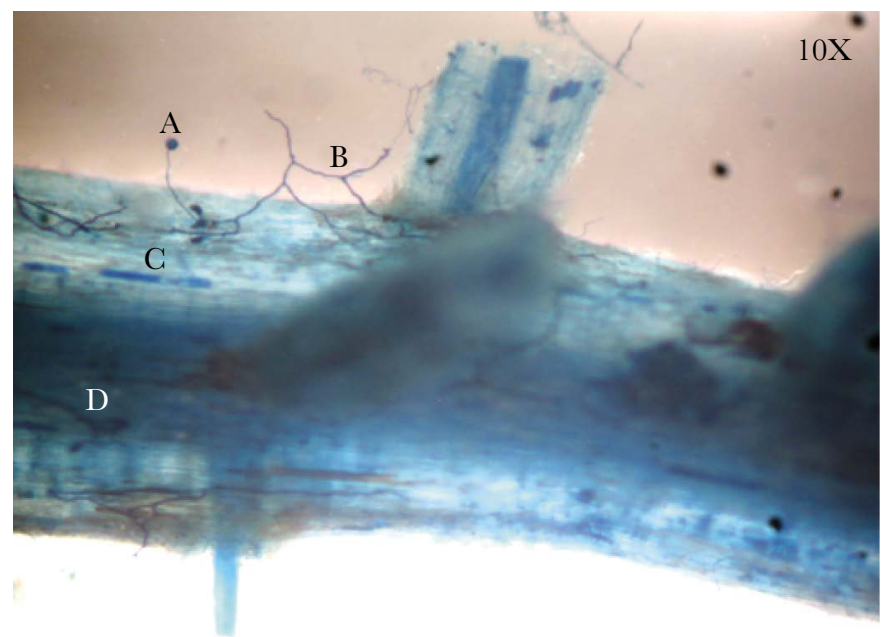

Figure 1. Fungal structures of VAM observed in sugarcane roots cultivated in the supply area of Ingenio Santa Rosalía: A) extra-root spore, B) extracellular hyphae, G) vesicles and D) intracellular hyphae. 

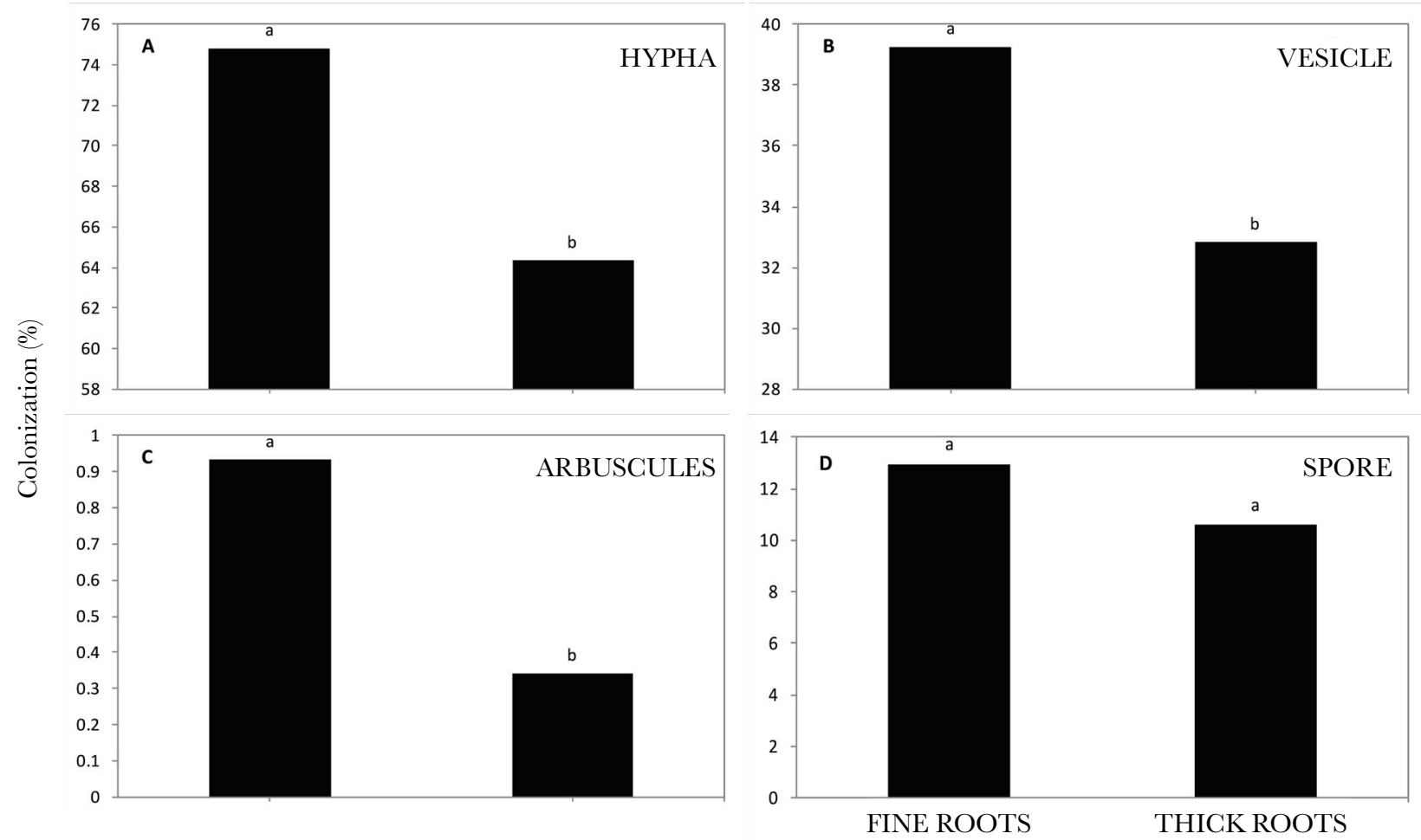

Figure 2. Mycorrhizal colonization (\%) by fungal structures (McGonigle et al., 1990), in fine roots (diameter $\leq 1 \mathrm{~mm}$ ) and thick roots (diameter 1 to $2.0 \mathrm{~mm}$ ) of sugarcane grown at Santa Rosalia sugar mill. Values with different literals indicate significant statistical difference (Tukey $\mathrm{p} \leq 0.05$ ).

Eutric Fluvisol (90.0\%), while the moderately acidic Eutric Vertisol was the one that showed the lowest percentage (54.2\%). Most of the soil subunits are grouped within the range of $62 \%$ to $79 \%$. These structures are the most abundant since they manage to disperse widely within the root tissue, from which other more specialized structures are formed.

The colonization by vesicles was higher in the eutric-gleyic-neutral Fluvisol subunits (50\%), in the moderately acidic eutric-gleyic Fluvisol (52\% a), and in the neutral pelic Vertisol (45\%), and lower in the moderately acidic Eutric Vertisol plot (11\%). The colonization by vesicles could indicate that the nutritional status of the sugarcane crop is adequate for the VAMs, which are storing nutritional reserves.

In relation to the other structures, colonization by arbuscules was minimal $(<1.9 \%)$ and colonization by spores was greater in the moderately acidic Eutric Fluvisol (37\%), followed by the moderately acidic eutric-gleyic Fluvisol (25.3\%), while the rest of the subunits showed lower percentages.

Intersect method. The ANOVA showed that there is no difference between the main effect of both root diameters; VAMs colonize both types of roots without showing statistically significant differences in colonization. It was observed that the thicker root segments are difficult to clarify and generally stain excessively; however, the cortical tissue of these segments was dissected, confirming the presence of fungal structures.

No significant differences were found in the main effect by soil subunit (Table 1), although arithmetic variations were observed. The highest mycorrhizal colonization is 
Table 1. Mycorrhizal colonization (\%) and colonization index by subunit of soil cultivated with sugar cane, in the supply area of Santa Rosalia sugar mill, Tabasco.

\begin{tabular}{|c|c|c|c|c|c|c|}
\hline \multirow{2}{*}{\multicolumn{2}{|c|}{ Subunit of soil }} & \multirow{2}{*}{$\begin{array}{c}\text { Colonization } \\
(\%)^{\mathrm{Z}}\end{array}$} & \multicolumn{4}{|c|}{ Colonization index $(\%)^{Y}$} \\
\hline & & & hyphae & vesicles & arbuscules & spores \\
\hline 1 & Fluvisol eutric neutral & $72.19 \mathrm{a}$ & $76.19 \mathrm{a}$ & $44.75 \mathrm{a}$ & $0.750 \mathrm{a}$ & $9.00 \mathrm{~b}$ \\
\hline 2 & Fluvisol eutric moderately acidic & $64.91 \mathrm{a}$ & $63.38 \mathrm{a}$ & $21.25 \mathrm{bc}$ & $0.125 \mathrm{a}$ & $10.13 \mathrm{~b}$ \\
\hline 3 & Fluvisol eutric-gleyic moderately acidic & $61.55 \mathrm{a}$ & $69.46 \mathrm{a}$ & $43.13 \mathrm{a}$ & $0.875 \mathrm{a}$ & $23.71 \mathrm{a}$ \\
\hline 4 & Gleysol eutric neutral & $63.51 \mathrm{a}$ & $75.13 \mathrm{a}$ & $31.63 \mathrm{ab}$ & $1.250 \mathrm{a}$ & $8.63 \mathrm{~b}$ \\
\hline 5 & Gleysol eutric moderately acidic & $78.20 \mathrm{a}$ & $75.88 \mathrm{a}$ & $33.00 \mathrm{ab}$ & $0.625 \mathrm{a}$ & $3.25 \mathrm{~b}$ \\
\hline 6 & Vertisol eutric moderately acidic & $62.35 \mathrm{a}$ & $54.25 \mathrm{a}$ & $11.00 \mathrm{c}$ & $0.625 \mathrm{a}$ & $3.38 \mathrm{~b}$ \\
\hline 7 & Vertisol pelic neutral & $78.47 \mathrm{a}$ & $67.88 \mathrm{a}$ & $40.31 \mathrm{a}$ & $0.125 \mathrm{a}$ & $7.50 \mathrm{~b}$ \\
\hline
\end{tabular}

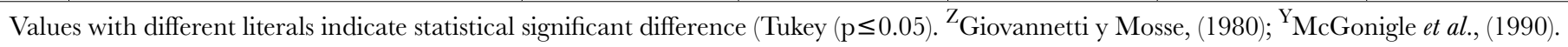

seen in the neutral pelic Vertisol (78.5\%), and the lowest in the moderately acidic eutricgleyic Fluvisol (61.5\%); this subunit of soil presents serious waterlogging problems in which the cane roots die from excess moisture. No trend was observed between the subunits and the soil $\mathrm{pH}$, with a mean root colonization of $68.5 \%$, considered to be acceptable according to various authors (Cracogna et al., 2002; Salgado et al., 2014; Tahuico, 2005), who report colonization at $70 \%, 88.9 \%$, and $69.8 \%$, respectively. The results indicate that mycorrhization is occurring in the ISR soils naturally in cultivated sugar cane.

Colonization index $(\%) \mathrm{Y}$

Vesicles Arbushes Spores

\section{Spores in the soil}

Figure 3 shows the number of spores in $100 \mathrm{~g}$ of soil. Tukey's test establishes three statistical groups. The highest number of spores was observed in the moderately acidic

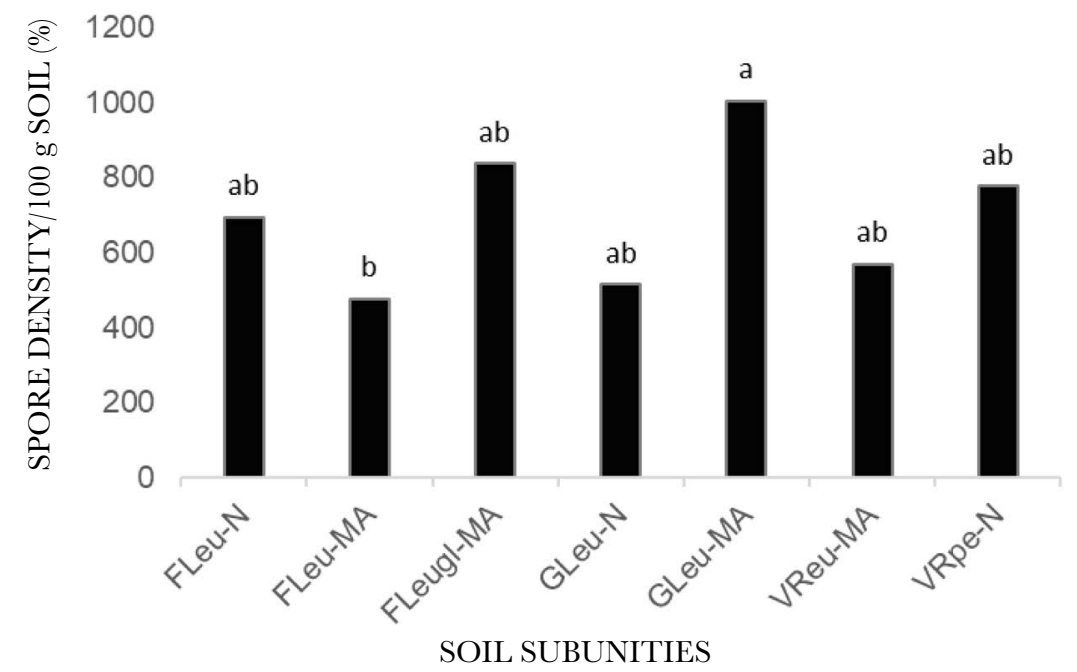

Figure 3. Density of spores per $100 \mathrm{~g}$ of soil in seven soil subunits cultivated with sugar cane at Santa Rosalia sugar mill supply area. Bars with different literals indicate statistically significant difference (Tukey p $\leq 0.05$ ). 
eutric Gleysol subunit (1005); and the lowest in the moderately acidic eutric Fluvisol subunit (477). The rest of the subunits presented values between 514 and 837 spores per $100 \mathrm{~g}$ of soil. The mean was 696 spores per $100 \mathrm{~g}$ of soil in the ISR, lower than that observed in the IPBJ (943 spores per $100 \mathrm{~g}$ of soil), which is explained by the greater variability in edaphoclimatic conditions as observed by Reis et al. (1999). In three localities cultivating sugarcane in Pernambuco and Rio de Janeiro, Brazil, a variation from 18 to 2070 spores per $100 \mathrm{~g}$ of soil was reported. The most abundant varieties CB 14-16 and SP 70-1284 presented 1630 and 1080 spores in $100 \mathrm{~g}$ of soil. The number of spores found in the ISR indicates a high presence of VAMs, compared to the 4 spores per $100 \mathrm{~g}$ of soil from the Ingenio Tres Valles sugar mill in Honduras (Thauico, 2005); or compared to saline soils cultivated with ancho pepper, sunflower, and corn, where 210, 400, and 280 spores are reported per $100 \mathrm{~g}$ of soil (Tapia-Goné et al., 2008).

Classification of VAM species. Six species of VAM were identified (Table 2). However, only four of them are present in more than four soil subunits: Glomus aff. deserticola, Glomus etunicatum, Glomus viscosum, and Paraglomus occultum. These results coincide with the predominance of the Glomus genus in sugarcane soils (Reis et al., 1999). However, the number of species in the soils of the ISR is lower when compared to the 16 species of VAM reported in the soils of the IPBJ (Salgado et al., 2014).

\section{CONGLUSIONS}

The analysis of mycorrhizal colonization by the intersects method did not show differences between the type of roots (thin or thick) but did detect significant differences in root colonization according to the soil subunits. The structures method detected significant differences by root type and showed significance in the colonization of hyphae, vesicles, and arbuscules, but not in the colonization by spores. In addition, statistically significant differences were observed in the colonization of roots according to the soil subunits. The highest number of spores was observed in the moderately acidic eutric Gleysol subunit (1005), and the lowest number in the moderately acidic eutric Fluvisol subunit (477). The rest of the subunits presented values between 514 and 837 spores per $100 \mathrm{~g}$ of soil. The average of 696 spores per $100 \mathrm{~g}$ of soil found in the ISR soils studied indicates a high presence of VAM. Six VAM species were found, of which four are present in more than four soil subunits: Glomus aff. deserticola, Glomus etunicatum, Glomus viscosum, and Paraglomus occultum. The presence of hyphae, vesicles, arbuscules, and spores indicates that there is an interactive process between VAM and sugarcane roots. Further research is recommended to determine if this relationship is symbiotic or parasitic given the low yields of grinding stalk obtained in the ISR.

\section{REFERENGES}

Azevedo, B.L.C. 2008. Comunidades de fungos micorrícicos no solo e raízes da cana-de-açúcar. Tese de Doutor. Escola Superior de Agricultura Luiz de Quiroz, USP. Piracicaba, Brasil. 111 p.

Barea, J.M., Pozo, M.J., Azcón, R., and Azcón-Aguilar, C. 2005. Microbial cooperation in the rhizosphere. Journal of Experimental Botany, 56(417):1761-1778.

UNG (Unión Nacional de Cañeros A.C. GNPR). 2018. Boletín Técnico de la Unión Nacional de Cañeros (35): 1- 7. Disponible en línea: www.caneros.org.mx. Fecha de consulta 29/11/2018. 
Table 2. Description and characteristics of morpho-species of hmva found in seven subunits of soil in the supply area of Santa Rosalia sugar mill, Mexico.

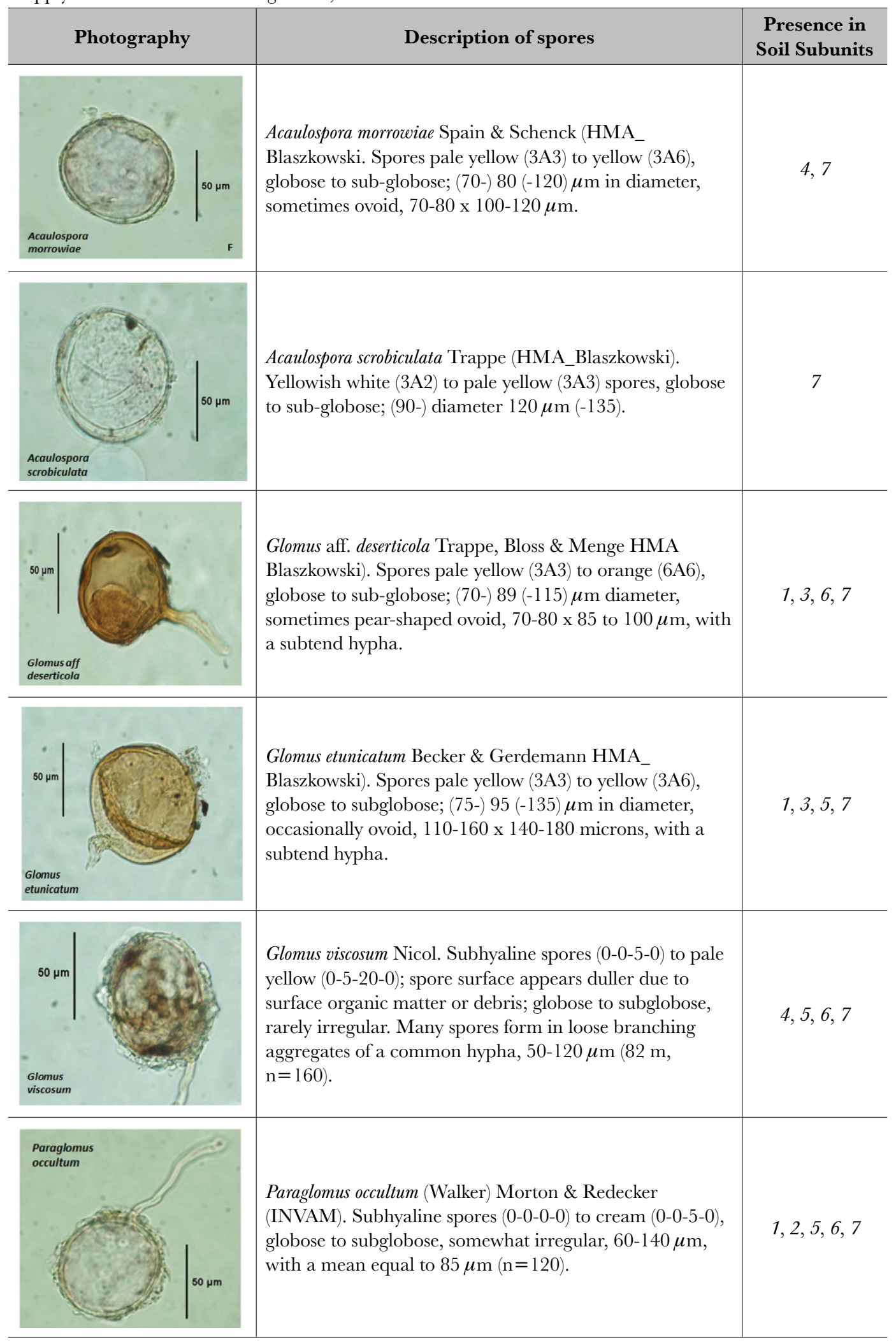


Cracogna, M.F., Fogar, M.N., Iglesias, M. y Rosso, J. 2002. Estudio exploratorio de la infección por micorrizas en caña de azúcar. wwwl.unne.edu.ar/cyt/2002/05-Agrarias/A-050.pdf, Fecha de consulta 02/03/2012.

Giovannetti, M. and Mosse, B. 1980. An evaluation of techniques for measuring vesicular arbuscular mycorrhizal infection in roots. New Phytologist 84 (3): 489-500.

INVAM (International culture collection of vesicular arbuscular mycorrhizal fungi). 2018. http://fungi.invam. wvu.edu/the-fungi/classification.html. Fecha de consulta 30/11/2018.

Salgado, G.S., Castelán E.M., Jiménez, J.R., Gómez, L.J.F., Osorio, M.M. 2014. Diversidad de hongos micorrícicos arbusculares en suelos cultivados con caña de azúcar en la región de la Chontalpa, Tabasco. Revista Mexicana de Micologia. 40: 2-16.

McGonigle, T.P., Miller, M.H., Evans, D.G., Fairchild, G.L., and Swan, J.A. 1990. A new method which gives an objective measure of colonization of roots by vesicular-arbuscular mycorrhizal fungi. New Phytologist $115(3): 495-501$.

Paula, M.A., Reis M.V., and Dobereiner, J. 1991. Interactions of Glomus clarum with Acetobacter diazotrophicus in infection of sweet potato (Ipomoea batatas), sugarcane (Saccharum spp.), and sweet sorghum (Sorghum vulgate). Biol. Fertil. Soils 17:111-115.

Philips, J.M. and Hayman, D.S. 1970. Improved procedures for clearing roots and staining parasitic and vesicular-arbuscular mycorrhizal fungi for rapid asessment of infection. Transactions of the British Mycological Society, 55: 158-160.

Reis, M.V., Puala, A.M., and Dobereiner, J. 1999. Ocorrência de micorrizas arbusculares e da bacteria diazotrofica Acetobacter Diazotrophicus em cana-de-açúcar. Pesq. agropec. bras. Brasília, 34 (10):1933-1941.

Requena, N., Serrano, E., Ocón, A., and Breuninger, M. 2007. Plant signals and fungal perceptions during arbuscular mycorrhizal establishment. Phytochemistry, 68: 33-40.

Salgado, G.S., Palma, L.D.J., Lagunes, E.L.C., Ortiz, G.C.F., y Ascencio, R.J.M. 2005. Bases para generar un programa sustentable de fertilización en un ingenio de Tabasco, México. Interciencia 30(7): 395-403.

Salgado, G.S., Palma, L.D., Castelán-Estrada M., Lagunes, E.L. y Ortiz, L.H. 2013. Manual para el muestreo de suelos, plantas y aguas e interpretación de análisis para la producción sostenible de alimentos. Colegio de Postgraduados. México. 108 p.

Sánchez-Reyna, L., Salgado-García, S., Córdova-Sánchez, S., Hernández-Cuevas, L., Gómez-Leyva, J.F., Palma-López, D.J., Castañeda-Ceja, R., García de la Cruz, R. 2020. Capacidad infectiva de propágulos de Hongos Micorrícicos Arbusculares en el cultivo de caña de azúcar. Agroproductividad 13(1): 59-66.

Smith, S.E., and Read, D. 2008. Mycorrhizal Symbiosis (Third Edition). Academic Press, New York. 219 p.

Soria, A.E.M., Reyes, E.C., Occeguera, A.Z., y Pereira, M.C. 2001. Micorrización de plántulas micropropagadas de caña de azúcar (Saccharum officinarum). Agricultura Técnica (Chile), 61(4):436-443.

Souza, L.S. 2006. Análise do proteoma de raízes de cana-de-acucar e da expresao de uma perosidase apoplástica responsiva a micorriza arbuscular. Tese de Doutor em Agronomia. Microbiologia Agricola. ESALQUSP. Brasil. 102 p.

Tahuico, R.J.S. 2005. Respuesta de caña de azúcar a la inoculación con micorrizas vesículo-arbusculares en el Ingenio Tres Valles, Honduras. Tesis de licenciatura. Zamorano, Honduras. 70 p.

Tapia-Goné,J., Ferrera-Cerrato, R., Varela-Fregoso, L., Rodríguez, O.J.C., Lara, M.J., Soria, G.J.C., Cuellar, T.H., Tiscareno, I.M.A. y Cisneros, A. R. 2008. Caracterización e identificación morfológica de hongos formadores de micorriza arbuscular, en cinco suelos salinos del estado de San Luis Potosí, México. Revista Mexicana de Micología. 26: 3-7.

Weier, K.C., McEwan, G.W., Vallis, I., Catchoole, V.R., and Myers, R.J. 1996. Potential for biological denitrification of fertilizer nitrogen in sugarcane soils. Aust.J. Agric. Res. 47: 67 